THURSDAY, JUNE 6, I889.

\section{REPORT OF THE ROYAL COMMISSION ON A UNIVERSITY FOR LONDON.}

$\mathrm{T}^{\mathrm{H}} \mathrm{s}$ IS Report is a disappointment. The spectacle of three eminent lawyers taking an eminently legal view of a question, and three teachers an educational view, is instructive and amusing, but it is not business. Passing over, for the present, the question how far its conclusions are discredited beforehand, by the dissent, on the material point at issue, of all the Commissioners who have had experience of teaching, we shall consider the principal Report from our own standpoint; which is that of a complete impartiality as between the University of London, the petitioning Colleges, and the other institutions and interests concerned, and of an earnest desire to see established in London a real University for teaching and research-that is to say, one of which the function is the dissemination and advancement of knowledge, while the examinations are relegated to their proper place, as accessories to study, not fetters on the teaching.

At first sight the impression is favourable. "The general case for a teaching University is," in the Commissioners' opinion, "made out." The limitation of its area to London, so far as concerns its teaching functions, is strongly insisted on, and reiterated in several paragraphs. The rejection of a separate University for Medicine is good in itself, and is of good omen, when the position of the two leading Commissioners is cons idered, for a future association with the University of the only possible London School of Law, that of the Inns of Court. The Commissioners have adopted some excellent ideas as to the constitution of Faculties, consisting exclusively of actual teachers, and as to the formation from the Faculties of Boards of Studies. They further "think it desirable to give a definite value to the training and teaching which those students will obtain who go through the prescribed courses of constituent colleges and teaching institutions connected with the University," and they formulate certain proposals for their exemption from specified examinations, which at least serve to show that the recognition thus given to the value of systematic study under competent guidance is not, in their minds, a purely nominal one. There cannot be a doubt that, if their recommendations were adopted, the administration of the University of London would be improved, and the influence of its examinations upon study, in London at all events, greatly modified for the better. We do not see why, subject to some further consideration for the case of students elsewhere than the Commissioners have cared to give, the reforms suggested in the Report should not now be carried out, as it proposes, by the independent action of the University of London, with hearty support and approval from the University Colleges, and without in the smallest degree impairing their case for the simultaneous establishment as a separate institution of a real teaching University for London.

But this, of course, is not the intention of the Commissioners. On the contrary, they recommend, in so many terms, that if this reform should take place in the VOL. XL. - NO. IO23.
University of London, "the prayer of University College and King's College be not granted." This obliges us to examine whether the reform in question will insure to us that further benefit to be expected from the establishment of a teaching University which lies apart from any possible good results to follow upon the mere perfecting of the machinery of examinations. Upon this head it is our deliberate judgment that they will fall short of what is needed. It is not the somewhat stinted amount of representation upon the Senate which is offered to University College and King's College ; not the representation on a more liberal scale of teachers in the University Colleges and schools, arranged in Faculties for the purpose, upon the same body; not even the appointment by these Faculties of so-called Boards of Studies, limited to the function of advising the examining body; nor yet all these concessions taken together, which will transform a general examining body into a teaching University for London, as we understand the term. Far less will such a University be constituted by "confederating " or "co-ordinating," for examining purposes only, all the "varions societies and institutions in London which profess to give advanced teaching," such as, for example, "the Birkbeck Institution, the City of London College, and the Working Men's College." In the Charter of the Victoria University it is expressly provided that the affiliated Colleges shall be, for teaching purposes, efficient. This necessary safeguard has been overlooked by the Commissioners. There remains the recommendation that " the University should have power to teach by professors and lecturers of its own, attached or unattached to particular Colleges or institutions, and to receive endowments for that purpose." Assuming the necessary endowment to be forthcoming, the bearing of this proposal depends on its application. If the University Colleges are willing to allow of the "attachment" to them of University professors-that is to say, to allow the University to appoint the leading members of their teaching staff-and if further they permit the University "Boards of Studies" to arrange their prospectuses, then, indeed, the result will be that the Colleges, for teaching purposes, will become merged in the University; and we shall have, at the expense of the sacrifice of their individuality, and not without considerable violence to their traditions, a strong and homogeneous teaching University in London. Otherwise, one of two things will happen : the separate University staff may be a mere peripatetic staff of lecturers, doing what is known as "University extension" work; or else it will constitute a third University College, with a privileged position, competing with others for their students. In neither of these cases shall we have reaped the characteristic benefit of a teaching University, which is, shortly, the organization of teaching power.

Thus, on the most careful examination we have been able to give to the proposals of the Report, we are brought to the conclusion that only on one condition-a condition very unlikely to be realized--will they result in giving us a real teaching University for London. In default, we shall have a general examining University as before, but one largely under the 'control of London teachers. The change will entail a violence to the traditions of the University, and perhaps a disparagement of its Imperial position. The Commissioners, indeed, say : "For other parts 
of the Kingdom, as for the Colomies, it is sufficient that there should be access, as heretofore, to examinations and to degrees." This dictum, a curiously inaccurate one, if we consider the recent foundation of the Victoria University, not to speak of Colonial and Indian teaching Universities, will hardly be accepted by the country Colleges which still look, and must for some time continue to look, to the University of London for degrees. They will claim representation on its governing body, if not also on its Faculties and Boards of Studies; and if its functions are restricted to the control of examinations, we do not see on what principle the claim can be refused. The refusal to admit institutions at a distance is justifiable if the first business of the University is to teach; but hardly plausible if its function is only to examine.

Nor is this all. In order to obviate "the risk of practical injustice being done to candidates for degrees from country Colleges or from no Colleges at all," the Commissioners propose to establish what they call a "balance in the government of the University and in determining the course of the examinations and the choice of examiners," between the associated institutions and "independent elements." This they attempt by assigning a majority in the governing body to Crown nominees and the representatives of Convocation. This provision will in no way help to keep the University in touch with the teaching of the country Colleges; but it will undoubtedly entail the risk, which has been overlooked by the Commissioners, of producing a want of flexibility in the administration of the examinations, considered as accessories to study in the London Colleges. The University will thus start on its teaching career with a clog about its movements. Differences of opinion are sure to arise among its administrators, as often as an alteration of its programme is proposed in the interests of the London teaching ; and these will be differences which no wisdom or moderation will entirely obviate, because they will be due to a fundamental difference in the point of view. We strongly apprehend that an institution so framed will be found to contain within itself the seeds of failure. In any case it will hardly obtain that large measure of confidence from the Colleges which would lead them to intrust it with any power over their teaching.

The initial fallacy of the whole Report may be traced to a little word in the twelfth page of it, paragraph 15 . The Commissioners say: "Whatever difficulties there may be in the way of establishment of such form of connection as may be desirable between a teaching University for London and the different bodies and agencies now engaged in kindred work on an independent footing, we think it probable that these difficulties may be more easily overcome if the ground were occupied by one University only, and not by two." The ground proposed to be covered is not one field of work, but two. There is the work of affording by means of a general examination a test of attainment for students in institutions of as yet imperfect efficiency, and for private students. There is also the work of organizing the teaching, with its examinations closely following and dependent on the teaching, in the efficient Colleges of London. The two differ essentially, not merely in area, but in purpose. The attempt to devise an instrument competent to regulate both at once has failed, as it was bound to fail.
Whatever line is now taken by the University of London, we trust that the promoters of the movement, who have succeeded hitherto so far beyond expectation, will stand fast by their principles, and not forfeit, by a too great eagerness for immediate results, the success which is certain ultimately to crown their efforts.

\section{TASMANIAN GEOLOGY.}

Systematic Account of the Geology of Tasmania. By Robert M. Johnston, F.L.S. Pp. 408, with Geological Map and Sections, and 57 Plates of Fossils. (Hobart : Published by the authority of the Government, I888.)

TEARLY forty-five years have elapsed since Count Strzelecki and Prof. J. Beete Jukes, working independently, made known to geologists the main features of the important island of Van Diemen's Land. In the interval between the publication of their researches and the present day, numerous papers treating on questions of local geology have been published by Mr. Charles Gould-who for a time was engaged in making a geological survey of the colony-and by many amateur geological investigators. No complete description of the geology of the whole colony has as yet appeared, however; and we therefore heartily welcome the large and comprehensive volume now lying before us, as supplying a long-felt and pressing want.

The author of this work, Mr. Robert M. Johnston is the Government Statistician and Registrar-General of Tasmania; and during the last sixteen years he has devoted much time and labour to the study of the geology and natural history of the colony in which he resides, and has published numerous papers dealing with questions of stratigraphical geology and palæontology, as well as of botany and zoology. In the year I884, Mr. Johnston was requested by the Tasmanian Government to write a general treatise on the geology of the island; and the present work has been prepared during the leisure hours of a busy Government official.

The Island of Tasmania has an area of a little more than 26,000 square miles, or between four and five times that of Yorkshire. Over large parts of the island there is a covering of almost impenetrable scrub; while the rivers are large enough to make traverses of the country by no means an easy task; and the rainfall is heavy. The interesting details of the methods of exploration, given in the introductory chapter of this work, illustrate the nature of the difficulties which have had to be overcome in making the researches upon which the work is based. We cannot but admire the energy and zeal which have been exhibited in carrying out the numerous and valuabie observations that have made the present work possible.

The excellent sketch-map of the geology of Tasmania, drawn on a scale of 15 miles to the inch, gives a very good idea of the general distribution of the several rockmasses. The oldest formations appear on the west and on the north-east of the island, and consist of crystalline schists, apparently belorging to the Archrean periods, associated with clayslates, quartzites, sandstones, and limestones of Cambrian, Ordovician, and Silurian age, with some small and doubtful representatives of the Devonian. The palæontological evidence concerning the 